\title{
PENGARUH NEGATIF DI ERA TEKNOLOGI INFORMASI DAN KOMUNIKASI PADA REMAJA (PERSPEKTIF PENDIDIKAN ISLAM)
}

\author{
Lita Kurnia', Ahmad Edwar ${ }^{2}$ \\ STAI La Tansa Mashiro Rangkasbitung ${ }^{1}$, STAI KH. Abdul Kabier Serang ${ }^{2}$ \\ Email: litakurnia86@gmail.com ${ }^{1}$, ahmadedwar9@gmail.com ${ }^{2}$
}

\begin{abstract}
The development of information and communication technology can no longer be avoided. Because with the information and communication technology, a person's life will feel easier. One can send messages easily, send and search for information quickly and easily. But behind these conveniences, it is necessary to pay attention to what are the negative impacts of information and communication technology on teenagers, especially teenagers today. In this era of information and communication technology, every effort and activity as well as deliberate action to achieve a goal must have the right foundation for a good and strong footing. Islamic religious education as an effort to shape human beings, must have a basis on which all activities and all formulation of the goals of Islamic education are linked. Islamic religious education in overcoming the negative influence of the era of information and communication technology on adolescents is the main educators for parents or the community who provide Islamic religious knowledge to adolescents so that they can fortify themselves in behaving, thinking, and acting in accordance with the provisions laid down. ordained by Allah SWT. for the safety of his life. According to the research title, this research is qualitative. Qualitative research is research that uses a natural setting in order to interpret phenomena that occur and is carried out with the intention of interpreting existing phenomena and is carried out by involving various existing methods, while the methods that are usually used are interviews, observation, and use of documents.
\end{abstract}

Keywords : information and communication technologies, islamic education 
Abstrak : Perkembangan teknologi informasi dan komunikasi tidak dapat lagi dihindari. Karena dengan adanya teknologi informasi dan komunikasi, hidup seseorang akan terasa lebih mudah. Sesorang dapat mengirim pesan dengan mudah, mengirim dan mencari informasi dengan cepat dan mudah. Namun dibalik kemudahan tersebut harus diperhatikan apa saja dampak negatif dari teknologi informasi dan komunikasi terhadap remaja apalagi remaja pada jaman sekarang. Dalam era teknologi informasi dan komunikasi ini, setiap usaha dan kegiatan serta tindakan yang disengaja untuk mencapai suatu tujuan harus mempunyai landasan yang tepat agar tempat berpijak yang baik dan kuat. Pendidikan Agama Islam sebagai suatu usaha membentuk manusia, harus mempunyai landasan ke mana semua kegiatan dan semua perumusan tujuan pendidikan Islam itu dihubungkan. Pendidikan agama Islam dalam mengatasi pengaruh negatif era teknologi informasi dan komunikasi pada remaja adalah para pendidik utamanya bagi orang tua atau masyarakat yang memberikan bekal ilmu agama Islam terhadap remaja agar mereka dapat membentengi dirinya sendiri dalam bersikap, berfikir, dan bertindak sesuai dengan ketentuan-ketentuan yang digariskan oleh Allah SWT. untuk keselamatan hidupnya. Sesuai judul penelitian, maka penelitian ini bersifat kualitatif. Penelitian kualitatif adalah penelitian yang menggunakan latar alamiah maksud menafsirkan fenomena yang terjadi dan dilakukan dengan maksud menafsirkan fenomena yang ada dan dilakukan dengan jalan melibatkan berbagai metode yang ada, sedangkan metode yang biasanya dimanfaatkan adalah interview, observasi, dan pemanfaatan dokumen.

Kata Kunci : teknologi informasi dan komunikasi, pendidikan islam 


\section{PENDAHULUAN}

Era teknologi informasi dan komunikasi dewasa ini sangat mempengaruhi perkembangan sosial budaya masyarakat Indonesia. Muslim tidak bisa terhindarkan dari arus perkembangan tersebut terutama bagi remaja-remaja. Apalagi jika ingin berjaya di tengah perkembangan dunia yang kian kompetitif di era sekarang ini yang disebut juga era Masyarakat Ekonomi Asean (MEA). Pendidikan Islam merupakan proses yang sangat baik untuk mewujudkan tujuan hidup bagi manusia, yaitu beribadah kepada Allah dengan segala maknanya yang luas. Dengan demikian, pendidikan merupakan bentuk tertinggi ibadah dalam Islam dengan alam sebagai lapangannya, manusia sebagai pusatnya, dan hidup beriman sebagai tujuannya. Manusia tidak mungkin dapat menjalankan tugastugas hidupnya tanpa memiliki cukup pengetahuan yang berkaitan dengan tugastugas itu serta kemampuan dan kemauan untuk menjalankannya.

Dalam pendidikan Islam ada dua unsur yang membentuk manusia dengan segala potensinya sama-sama mendapat perhatian, yaitu unsur jasmani dan unsur rohani ${ }^{1}$. Kalau unsur jasmani dan rohani mendapat perhatian yang sama, maka demikian pula aspek akal dan perasaan pada unsur rohani mendapat porsi perhatian yang seimbang dalam pendidikan Islam.

Dengan demikian, Islam memandang bahwa pendidikan merupakan cara paling berpengaruh dalam menanggulangi pengaruh-pengaruh negatif terhadap prilaku atau sikap bagi remaja di era teknologi informasi dan komunikasi sekarang ini. Dan pendidikan itu menurut Islam bukan hanya transfer pengetahuan tetapi juga transfer nilai dan budaya. Melalui pendidikan agama Islam diharapkan seseorang dapat meningkatkan kualitas iman dan taqwa kepada Allah SWT, agar dapat terhindar dari bahaya yang mengancamnya, yakni pengaruh negatif era teknologi informasi dan komunikasi termasuk di dalamnya penyalahgunaan narkoba.

Penyalahgunaan narkoba biasanya diawali dengan pemakaian pertama pada usia SD atau SMP, karena tawaran, bujukan, dan tekanan seseorang atau kawan sebaya. Didorong rasa ingin tahu atau ingin mencoba, mereka mau menerimanya, sampai menjadi ketergantungan terhadap zat yang digunakan. Anak atau remaja memiliki kehendak bebasnya sendiri, sebagai hak individu yang tidak dapat diganggu gugat. Para orang tua atau pendidik tidak dapat memaksa anak, untuk melakukan atau tidak melakukan sesuatu tanpa persetujuannya, yaitu pecandu narkotika.

Narkoba yang sering disalahgunakan dan menyebabkan ketergantungan antara lain heroin atau putauw, sabu, ekstasi, obat penenang dan obat tidur, ganja dan kokain. Tembakau dan alkohol atau minuman keras yang sering disalahgunakan pada remaja, juga menimbulkan ketergantungan. ${ }^{2}$

Dengan demikian, bahwa pendidikan agama Islam dalam menanggulangi pengaruh negatif era teknologi informasi dan komunikasi pada remaja adalah para pendidik utamanya bagi orang tua atau masyarakat memberikan bekal ilmu agama Islam terhadap remaja agar mereka dapat membentengi dirinya sendiri dalam bersikap, berfikir, dan bertindak sesuai dengan ketentuan-ketentuan yang digariskan oleh Allah SWT untuk keselamatan hidupnya.

\footnotetext{
${ }^{1}$ Hery Noer Aly dan Munzier,Watak Pendidikan Islam, (Jakarta: Friska Agung Insani, 2000), h. 130 .

${ }^{2}$ Lydia Harlina Martono dan Satya Joewana,Pencegahan dan Penanggulangan Penyalahgunaan Narkoba Berbasis Sekolah, (Jakarta: Balai Pustaka, 2006), h. 1.
} 


\section{METODE PENELITIAN}

Jenis penelitian yang digunakan dalam penelitian ini adalah penelitian kualitatif (qualitative research), yaitu suatu penelitian yang ditunjukan untuk mendeskripsikan dan menganalisis fenomena, pristiwa, aktivitas sosial, sikap kepercayaan, persepsi, pemikiran orang secara individu maupun kelompok, ${ }^{3}$

Analisis data dalam penelitian ini adalah, Content Analysis (analisis isi), yaitu sebuah teknik yang digunakan untuk memahami teks-teks sambil merekonstruksikannya sehingga memperoleh makna dan nuansa uraian yang disajikan secara khas. Teks dan konten yang didapat dari sumber primer dan sekunder analisis menggunakan sumber referensi lain dan analisis penulis, sehingga memunculkan penguatan pemikiran dan inovasi pikiran.

\section{HASIL DAN PEMBAHASAN}

\section{Pengertian Remaja}

Remaja berasal dari kata latin adolensence yang berarti tumbuh atau tumbuh menjadi dewasa. Istilah adolensence mempunyai arti yang lebih luas lagi yang mencakup kematangan mental, emosional sosial dan fisik Remaja sebenarnya tidak mempunyai tempat yang jelas karena tidak termasuk golongan anak tetapi tidak juga golongan dewasa atau tua. Masa remaja menunjukkan dengan jelas sifat transisi atau peralihan karena remaja belum memperoleh status dewasa dan tidak lagi memiliki status anak. Demikian pula, masa remaja merupakan suatu periode atau masa tumbuhnya seseorang dalam masa transisi dari anak-anak kemasa dewasa, yang meliputi semua perkembangan yang dialami sebagai persiapan memasuki masa dewasa.

Masa remaja adalah suatu masa disaat individu berkembang dari pertama kali menunjukkan tanda-tanda seksual, mengalami perkembangan psikologis dan pola identifikasi dari anak menjadi dewasa, serta terjadi peralihan dari ketergantungan sosial ekonomi yang penuh pada keadaan yang mandiri dan masa di mana pengambilan keputusan meningkat. ${ }^{4}$ Oleh karena itu, masa remaja merupakan masa peralihan dan ketergantungan pada masa anak-anak kemasa dewasa, dan pada masa ini remaja dituntut untuk mandiri. Selanjutnya, Daradjat mengatakan masa remaja adalah masa dimana munculnya berbagai kebutuhan dan emosi serta tumbuhnya kekuatan dan kemampuan fisik yang lebih jelas dan daya fikir yang matang. ${ }^{5}$

Masa remaja adalah masa kritis identitas atau masalah identitas ego remaja. Identitas diri yang dicari remaja berupa usaha untuk menjelaskan siapa dirinya dan apa perannya dalam masyarakat, serta usaha mencari perasaan kesinambungan dan kesamaan baru para remaja harus memperjuangkan kembali dan seseorang akan siap menempatkan idola dan ideal seseorang sebagai pembimbing dalam mencapai identitas akhir.

Berdasarkan beberapa pengertian remaja yang telah dikemukakan para ahli, maka dapat ditarik kesimpulan bahwa remaja adalah individu yang sedang

\footnotetext{
${ }^{3}$ Nana Syaodih Sukmadinata, Metode Penelitian Pendidikan, (Bandung: Remaja Rosda Karya, 2005), h.60.

${ }^{4}$ John W. Santrock, Life-Span Development; Perkembangan

Masa Hidup, (Jakarta: Erlangga,2002), h. 16.

${ }^{5}$ Zakiah Drajat, Pendidikan Islam dalam Keluarga dan Sekolah, (Jakarta: Ruhama, 1994), h. 330 .
} 
berada pada masa peralihan dari masa anak-anak menuju masa dewasa dan ditandai dengan perkembangan yang sangat cepat dari aspek fisik.

2. Ciri-Ciri Remaja

Ciri perkembangan psikologis remaja adalah adanya emosi yang meledakledak, sulit dikendalikan, cepat depresi (sedih, putus asa) dan kemudian melawan dan memberontak. Emosi tidak terkendali ini disebabkan oleh konflik peran yang senang dialami remaja. Oleh karena itu, perkembangan psikologis ini ditekankan pada keadaan emosi remaja.

Keadaan emosi pada masa remaja masih labil karena erat dengan keadaan hormon. Suatu saat remaja dapat sedih sekali, dilain waktu dapat marah sekali. Emosi remaja lebih kuat dan lebih menguasai diri sendiri dari pada pikiran yang realistis. Kestabilan emosi remaja dikarenakan tuntutan orang tua dan masyarakat yang akhirnya mendorong remaja untuk menyesuaikan diri dengan situasi dirinnya yang baru. Hal tersebut hampir sama dengan yang dikemukakan oleh Hurlock (1990), yang mengatakan bahwa kecerdasan emosi akan mempengaruhi cara penyesuaian pribadi dan sosial remaja. Bertambahnya ketegangan emosional yang disebabkan remaja harus membuat penyesuaian terhadap harapan masyarakat yang berlainan dengan dirinya.

Menurut Mappiare (dalam Hurlock, 1990) remaja mulai bersikap kritis dan tidak mau begitu saja menerima pendapat dan perintah orang lain, remaja menanyakan alasan mengapa sesuatu perintah dianjurkan atau dilarag, remaja tidak mudah diyakinkan tanpa jalan pemikiran yang logis. Dengan perkembangan psikologis pada remaja, terjadi kekuatan mental, peningkatan kemampuan daya fikir, kemampuan mengingat dan memahami, serta terjadi peningkatan keberanian dalam mengemukakan pendapat.

Ciri-ciri masa remaja adalah sebagai berikut :

a. Masa remaja sebagai periode yang penting, karena perkembangan fisik, mental yang cepat dan penting dan adanya penyesuaian mental dan pembentukan sikap, nilai dan minat baru.

b. Masa remaja sebagai periode peralihan, adanya suatu perubahan sikap dan perilaku dari anak-anak ke menuju dewasa.

c. Masa remaja sebagai periode perubahan, karena ada 5 perubahan yang bersifat universal yaitu perubahan emosi, tubuh, minat dan pola perilaku, dan perubahan nilai.

d. Masa remaja sebagai usia bermasalah, karena pada masa kanak-kanak masalah-masalahnya sebagian besar diselesikan oleh gurudan orang tua sehingga kebanyakan remaja kurang berpengalaman dalam mengatasi masalah.

e. Masa remaja sebagai masa mencari identitas, karena remaja berusaha untuk menjelaskan siapa dirinya, apa peranannya.

f. Masa remaja sebagai usia yang menimbulkan ketakutan, karena adanya anggapan stereotip budaya bahwa remaja adalah anak-anak yang tidak rapih, yang tidak dapat dipercaya dan cenderung merusak, menyebabkan orang dewasa harus membimbing dan mengawasi.

g. Masa remaja sebagai masa yang tidak realistik. Karena remaja melihat dirinya sendiri dan orang lain sebagaimana yang diinginkan dan bukan sebagaimana adanya terlebih dalam cita-cita.

h. Masa remaja sebagai ambang masa dewasa, karena remaja mulai memusatkan diri pada perilaku yang dihubungkan dengan orang dewasa. 
Berdasarkan uraian di atas, dapat di ambil kesimpulan bahwa ciri ciri masa remajaadalah merupakan periode yang penting, periode perubahan, peralihan, usia yang bermasalah, pencarian identitas, usia yang menimbulkan ketakutan, masa yang tidak realistik dan ambang masa kedewasaan.

3. Fase Remaja

fase remaja digolongkan menjadi dua bagian yaitu:

a. Masa awal remaja (12-18 tahun) dapat dibagi ke dalam dua sub tahapan sebagai berikut:

1. Sikap negatif (meskipun tidak selalu terang-terangan) disebabkan alam pikirannya yang kritis melihat kenyataan orang-orang beragama secara hipocrit (pura-pura) yang pengakuan dan ucapannya tidak selalu selaras dengan perbuatannya.

2. Pandangan dalam hal ke-Tuhanannya menjadi kacau karena ia banyak membaca atau mendengar berbagai konsep dan pemikiran atau aliran paham banyak yang tidak cocok atau bertentangan satu sama lain.

3. Penghayatan rohaniahnya cenderung skeptic (diliputi kewas-wasan) sehingga banyak yang enggan melakukan berbagai kegiatan ritual yang selama ini dilakukannya dengan kepatuhan.

Masa remaja akhir yang ditandai antara lain oleh hal-hal berikut ini:

1. Sikap kembali, pada umumnya, kearah positif dengan tercapainya kedewasaan intelektual, bahkan agama dapat menjadi pegangan hidupnya menjelang dewasa.

2. Pandangan dalam hal ke-Tuhanan dipahamkannya dalam konteks agama yang dianut dan dipilihnya.

Penghayatan rohaniahnya kembali tenang setelah melalui proses identifikasi dan merindu puja ia dapat membedakan antara agama sebagai doktrin atau ajaran dan manusia penganutnya, yang baik shalih dari yang tidak. Ia juga memahami bahwa terdapat berbagai aliran paham dan jenis keagamaan yang penuh toleransi seyogyanya diterima sebagai kenyataan yang hidup didunia ini.

4. Pendidikan Islam pada Remaja di Era Tekonologi Informasi dan Informasi

Istilah teknologi informasi dan komunikasi sering diberi arti yang berbeda antara yang satu dengan yang lainnya. Pada prinsipnya mengacu pada perkembangan-perkembangan yang pesat di dalam teknologi komunikasi, transformasi, informasi yang bisa membawa bagian-bagian dunia yang jauh mudah dijangkau dengan mudah. Era teknologi informasi dan komunikasi ini berarti terjadi pertemuan dan gesekan nilai-nilai budaya dan agama di seluruh dunia yang memnfaatkan jasa komunikasi, transformasi dan informasi hasil modernisasi. ${ }^{6}$

Pada era ini, para remaja perlu diberi bimbingan pendidikan khususnya mereka yang tinggal di negara-negara non-Muslim atau di negara Islam tapi di kota-kota besar. Mereka tidak pernah atau jarang melihat sikap positif terhadap Islam, baik dalam keluarga, di sekolah maupun di masyarakat. Dalam situasi seperti ini tentu merupakan tanggung jawab orang tua untuk menanamkan nilainilai moral pada anak remaja, barbagi pengalaman kehidupan Islami yang pada gilirannya akan mengarah pada internalisasi misi Al-Qur"ean dan Sunnah.

Peran orang tua seperti ini akan sangat membantu remaja-remaja dalam memasuki kehidupan yang fungsional sebagai Muslim yang dewasa dan sebagai

${ }^{6}$ A. Qadri Azizy,Melawan Globalisasi; Reinterpretasi Ajaran Islam, (Yogyakarta: Pustaka Pelajar, 2004), h. 20. 
anggota yang aktif dalam komunitas Islam. Apabila anak remaja menampakkan tanda-tanda sikap yang negatif terhadap Islam yang disebabkan oleh pengaruh dari sekolah atau masyarakat atau karena kecerobohan dan kelengahan orang tua, maka hal ini akan mengakibatkan penolakan anak terhadap hidup Islami dan akan gagal berintegrasi dengan komunitas Islam.

Oleh karena itu, orang tua bertugas untuk mengatur strategi yangtepat dalam rangka membantu proses pembentukan pribadi anak. Dalam hal ini, orang tua haruslah memiliki wawasan pengetahuan yang luas serta dasar pengetahuan agama yang mencukupi untuk menghindari kesalahan strategi dalam mendidik anak. Kemudian, mengalokasikan waktu yang cukup untuk memberikan kesempatan bagi anak berinteraksi serta meresapi sikap-sikap Islami yang ditunjukkan oleh orang tua dalam perilaku kesehariannya. Persoalannya adalah secara faktual tidak semua orang dapat memenuhi kriteria-kriteria di atas yang disebabkan oleh hal-hal sebagai berikut; orang tua, terutama ibu, tidak memiliki wawasan pengetahuan yang mempuni, khususnya di bidang pedagogi anak dan nilai-nilai dasar Islami.

Dalam situasi semacam ini orang tua perlu mengambil langkah-langkah sebagai upaya mengantar anak remaja menuju pintu gerbang masa depan yang cerah, sehat dan agamis, sebagai berikut:

a) Mendatangkan guru privat agama pada waktu usia anak di abwah dua belas tahun untuk mengajarkan nilai-nilai dasa Islam, termasuk cara membaca AlQur'ean dan Hadits. Pada usia tiga belas tahun sampai dengan delapan belas tahun kandungan makna Al-Qur'an dan Hadits mulai diajarkan dengan metode yang praktis, sistematis dan komprehensif, mengingat pada periode ini anak sudah mulai disibukkan dengan pelajaran-pelajaran di sekolah. Dengan demikian, diharapkan ketika memasuki bangku kuliah anak remaja sudah memiliki gambaran pendidikan islam yang utuh dan komprehensif tentang Islam, beserta nilai-nilai abadi yang terkandung di dalamnya. Sehingga ia tidak akan mudah menyerah terhadap tekanan-tekanan dan pengaruh-pengaruh luar yang bertentangan dengan nilai-nilai Islam, minimal ia akan tahu ke mana jalan untuk kembali ketika, oleh pengaruh eksternal yang terlalu kuat, ia melakukan penyimpangan-penyimpangan dari nilai-nilai Islam.

b) Menyekolahkan anak sejak dari SMP sampai SMA di lembaga-lembaga Islam semacam pesantren modern yang saat ini sudah banyak memiliki sekolah-sekolah umum yang berkualitas. Ketiga, memasukkan anak sejak TK sampai SMA di lembaga-lembaga pendidikan yang memakai lebel Islam, seperti Yayasan Muhammadiyah, Yayasan NU, Yayasan al-Azahar dan lain-lain. Akan tetapi alternatif ketiga ini dalam pengamatan penulis tidak begitu efektif. Salah satu sebabnya adalah karena kurang komprehensifnya kurikulum keislaman di dalamnya. Kendatipun begitu, ini jauh lebih baik disbanding, misalnya, memasukkan anak ke sekolah-sekolah non-Muslim. Memang menyekolahkan anak ke sekolah-sekolah nonMuslim tidak berarti anak tersebut akan terkonversi ke agama lain, tetapi dampak minimal yang tak terhindarkan adalah timbulnya sikap skeptis dan apatis anak terhadap Islam. Alhasil, semakin kuat nilai-nilai agama tertanam akan semakin kokoh resistansi anak remaja terhadap pengaruh-pengaruh 
negatif dari luar. Sifat agamis bangsa Indonesia dalam tingkat yang cukup besar tidak mengalami pengikisan. ${ }^{7}$

Secara faktual hampir seluruh negara-negara Islam. baru terlepas dari belenggu penjajahan Barat di akhir abad dua puluh tepatnya sekitar 1950-an. Pada umumnya terjadinya pemindahan kekuasaan dari penjajah ke tangan pribumi menimbulkan terjadinya perubahan politik di negara-negara tersebut yang sebagai akibatnya tertundanya reformasi pendidikan yang dicita-citakan sebelumnya. Rezim kekuasaan yang baru pasca kolonialisme tidak mampu memfokuskan diri pada tugas ini. Fokus utama mereka adalah bagaimana mempertahankan kekuasaan di tengah-tengah terjadinya kekacauan politik. Oleh karena itu pegnembangan dan reformasi pendidikan menjadi terabaikan untuk beberapa waktu. Pendidikan hanya menjadi bagian dari retorika politik dan rencana-rencana pengembangan pendidikan terartikulasi tanpa adanya pencapaian yang berarti. Dewasa inipun anggaran negara yang dicangkan untuk program pendidikan di negara-negara Islam relatif sangat rendah sehingga infrastruktur pendidikan yang mutlak diperlukan tidak atau jarang tersedia

Hal ini menimbulkan dampak-dampak yang tidak efektif, seperti pelajar yang hendak memperdalam ilmunya terpaksa harus pergi ke luar negeri yang biayanya relatif lebih mahal apalagi kalau tujuan belajarnya di negara-negara maju. Sementara kecenderungan belajar ke luar negeri ini menimbulkan persoalan tersendiri khususnya bagi mereka yang secara ekonomis kurang mampu.

Lembaga-lembaga Islam tradisional semacam pesantren, khususnya pesantren salaf perlu melepaskan diri dari blue-print lamanya dan memodernisasi system dan metede pendidikannya agar tidak tertinggal dengan perkembangan keilmuan modern yang melajubegitu pesat. Sementara itu sesuai dengan latar belakang dan kecenderungan yang berbeda, para ilmuwan terbagi dalam dua kategori, yaitu: (1) ilmuwan agama, yakni ilmuwan yang mengadakan pengkajian khusus berbagai disiplin ilmu agama dan (2) ilmuwan umum, yakni para pakar yang mengambil spesifikasi berbagai disiplin ilmu duniawi kontemporer. Para ilmuwan umum tentunya akan ,menggarap ${ }^{\text {ee }}$ lading yang sesuai dengan bidangbidang yang menjadi keahlian mereka masing-masing sementara fungsi para ilmuwan agama di sini adalah: (1) sebagai mediator antara aspirasi umat dengan para pakar iptek, (2) mengadakan hubungan yang proporsional dengan para pakar komunikasi massa dalam rangka memanfaatkan media massa, khususnya televisi dan internet, sebagai upayaunifikasi dan pengembangan umat dan (3) menyatukan paradigma para pakar iptek Muslim bahwa apa yang akan, sedang dan telah diperbuat selalu mengandung dua dimensi yaitu pengabdian kepada Allah (ibadah) dan untuk kebaikan serta rahmat seluruh umat manusia.

Apabila disebut istilah teknologi informasi dan komunikasi, rata-rata masyarakatsudah mengetahui danmemahami istilah tersebut. Efek teknologi informasi dan komunikasi bermaksud mensosialisasikan pola atau sistem tertentu yang dimiliki oleh suatu negara atau kelompok sehingga menembus seluruh dunia. Dunia ingin dijadikan suatu pentas kecil supaya mudah dijangkau dalam waktu yang singkat.

Pengaruh positif teknologi informasi dan komunikasi sudah tentu perlu dimanfaatkan pengaruh negatifnya harus ditolak dan ditangani dengan bijaksana. Hakikatnya, teknologi informasi dan komunikasi juga dikhawatirkan oleh

7 Azymardi Azra,Pendidikan Islam; Tradisi dan Modernisasi Menuju Milenium Baru, (Jakarta: Logos Wacana Ilmu, 2002), h. 47. 
beberapa pihak tentang kemerosotan nilai akhlak dan moral manusia serta sistem agama dalam cara hidup dan kebudayaan yang diamalkan. Maka dengan itu,harus dipikirkan cara terbaik untuk menerapkan nilai mulia dan membentuk insan mulia. Sekolah dan pendidikan merupakan wadah yang dapat memainkan peran ini.

5. Bentuk-Bentuk Pengaruh Negatif Teknologi Informasi dan Komunikasipada Remaja

Teknologi informasi dan komunikasi memiliki beberapa dampak negatif yang cukup mengganggu kehidupan sehari-hari. Kebanyakan dampak tersebut disebabkan karena penyalahgunaan dari teknologi informasi dan komunikasi, ataupun disebabkan karena kurangnya pemahaman user akan etika dan juga cara untuk menggunakan teknologi informasi dan juga komunkasi dengan baik dan juga benar.

Berikut ini adalah beberapa dampak negative dari teknologi informasi dan juga komunikasi:

a. Individu menjadi malas untuk bersosialisasi secara fisik

b. Meningkatnya penipuan dan juga kejahatan cyber

c. Cyber Bullying

d. Konten negative yang berkembang pesat

e. Fitnah dan juga pencemaran nama baik secara luas

f. Menjauhkan yang dekat

g. Mengabaikan tugas dan juga pekerjaan

h. Mebuang-buang waktu untuk hal yang tidak berguna

i. Menurunnya prestasi belajar dan juga kemampuan bekerja seseorang. ${ }^{8}$

Seiring dengan bertambahnya usia, remaja mengalami proses belajar pada kehidupan sosial maupun pola-pola tingkah laku orang dewasa. Seringkali para remaja mengalami kebingungan dalam menemukan status dirinya secara utuh. Salah satu hal yang seringkali menyerang remaja adalah perilaku merokok yang biasanya didapatkan dari lingkungan tempat tinggal, orang tua, ataupun temanteman. Selain itu, adalah narkoba yang mempunyai beberapa pengaruh negatif, diantaranya: terganggu fungsi otak dan perkembangan normal remaja, keracunan, overdosis gejala putus zat, berulang kali kambuh, gangguan prilaku/mental-sosial, gangguan kesehatan, kendornya nilai-nilai, serta keuangan dan hokum. ${ }^{9}$ Karena remaja pada dasarnya labil dan merasa sudah cukup dewasa untuk melakukan apa saja, ditambah dengan jiwa pemberontak yang menggelora, maka gampang sekali untuk mengikuti pengaruh buruk dari luar dirinya tersebut.

Remaja lelaki yang pada kenyataannya lebih banyak merokok dibandingkan perempuan. Mereka biasanya mulai merokok karena pengaruh teman-temannya, karena bila tidak merokok akan dikatakan tidak jantan, tidak gaul, dll. Padahal merokok sama sekali tidak menunjukkan kejantanan. Bisa juga dari orang tua. Karena setiap hari melihat orang tuanya merokok, sang anak jadi merasa bahwa itu bukan tidakan yang salah, maka mereka pun mulai menirunya.

Meskipun perilaku merokok atau pecandu narkoba itu perbuatan yang tidak baik, namun bila yang melakukannya kaum lelaki, hal itu masih dianggap wajar. Berbeda dengan wanita perokok, kebanyakan orang akan langsung beranggapan buruk mengenai wanita yang merokok. Perilaku merokok membuat

\footnotetext{
8 http://dosenit.com/kuliah-it/teknologi-informasi/dampak-positif-dan-negatif-penggunaanteknologi-informasi-dan-komunikasi

${ }^{9}$ Lydia Harlina Martono dan Satya Joewarna,op.cit., h. 24.
} 
image wanita tersebut terlihat tidak baik, karena berkaitan dengan budaya yang ada yang menganggap bahwa wanita itu harus bersikap anggun. Selain itu, merokok juga membawa berbagai dampak negatif pada tubuh wanita, seperti gangguan kehamilan dan janin, gangguan hormon, menopause dini, dan lainlain.

Merokok adalah tindakan yang sangat merugikan kesehatan, baik bagi diri sendiri maupun orang lain, dan penyalahgunaan narkoba merupakan penggunaan narkoba yang dilakukan tidak untuk maksud pengobatan, tetapi karena ingin menikmati pengaruhnya, dalam jumlah berlebihan dan berlangsung cukup lama, sehingga menyebabkan gangguan kesehatan fisik, mental, dan kehidupan social. ${ }^{10}$ Selain banyak menghabiskan dana yang seharusnya bisa dimanfaatkan untuk yang lain, rokok juga mengandung banyak zat racun yang dapat merusak tubuh. Maka dari itu, sangat disayangkan apabila potensi-potensi yang terdapat dalam diri tiap generasi muda, baik secara psikis maupun fisik, tenggelam begitu saja akibat rokok. Untuk membantu mencegahnya, atau paling tidak mengurangi, perlu diadakan semacam kampanye. Anak muda identik dengan berbagai hal,ada yang memilih untuk identik dengan olahraga, fashion, musik, dan lain-lain. Oleh karena itu, dipilihlah musik sebagai media untuk menyampaikan pesan anti rokok tersebut pada mereka.

Berkembangnya pertelevisian, maraknya berita-berita nasional yang bersifat public interest, serta pesatnya informasi dan komunikasi pada akhirnya menumbuhkan rasa cemas pada orang-orang tua yang memiliki anak usia remaja. Berkali-kali ditayangkan pelajar selevel sekolah menengah yang digiring ke kantor polisi karena tawuran. Hanya karena urusan sepele, dua kelompok pelajar baku hantam dan saling lempar batu di jalan. Premanisme, pencurian motor, perjudian yang saat terungkap pelakunya ternyata adalah remaja.Mungkin pendidikan belum sempurna, dan masih banyak pekerjaan rumah yang harus dikerjakan untuk membangun sebuah sistem yang lebih baik. Namun demikian, sebenarnya juga perlu dipertanyakan seberapa proporsional pemberitaanpemberitaan tersebut. Seperti dipahami, fenomena yang terjadi di alam pada umumnya adalah distribusi normal. Artinya, kelompok pelajar yang berperilaku menyimpang berada di sisi lain dari kelompok pelajar yang penuh prestasi. Jumlah kedua ekstrim ini sebenarnya tidak banyak. Yang paling banyak justru pelajar yang "sedang-sedang" atau "biasa-biasa" saja. Kalau nakal, masih nakalnya remaja. Kalau pun berprestasi, masih dalam taraf prestasi yang normal.

Sejak dulu, menghadapi remaja tidak pernah mudah. Pola pikir dan pola asuh orang tua kepada anaknya yang sudah terbentuk sejak lama harus berubah saat anak memasuki usia remaja. Dalam pengertian umum, masa remaja adalah tahap transisional perkembangan fisik dan mental manusia yang terjadi antara masa anak-anak dan dewasa. Transisi ini meliputi perubahan biologis (pubertas), sosial, dan psikologis, akan tetapi perubahan biologis dan fisiologis yang paling mudah diukur secara objektif. Bukan hanya orang tua yang mengalami kebingungan dalam menghadapi perubahan anak, anak itu sendiri pun mengalami kebingungan dengan perubahan yang terjadi pada dirinya sendiri. Misalnya anak remaja putus sekolah. Dengan putus sekolah banyak anak di usia remaja memiliki

\footnotetext{
${ }^{10}$ Ibid.,h. 17.
} 
keterbatasan pendidikan yang akhirnya dapat mengurangi kesejahteraan ekonomi dan sosial sepanjang kehidupan dewasa mereka. ${ }^{11}$

Bila secara fisik pubertas ditandai dengan munculnya sex sekunder sehubungan kematangan organ-organ seksual, secara psikologis muncul perubahaan mood yang dikenal sebagai mood swings. Tidak heran, emosi remaja sering berubah seketika dan tidak diduga-duga. Kecenderungan untuk berinteraksi dan bergantung pada peer (teman sebaya) juga merupakan salah satu ciri perkembangan remaja, dan menggeser makna penting keluarga dengan peer group (kelompok sebaya). Tidak mengherankan bila kemudian kelompok mendominasi kehidupan remaja, dan semakin menjauhi orang tua bila sang orang tua tidak bijak menyikapi kondisi ini. Berdasarkan hal ini, dapatdipahami bahwa budaya berkelompok dan geng adalah ciri remaja, sehingga semakin keras orang tua menekan anak untuk berpisah dengan peer group yang cocok dengannya, semakin bingung anak menetapkan pilihannya.

Dalam kehidupan berkelompok, dikenal istilah peer pressure (tekanan kelompok), yang biasanya berkaitan dengan norma dan kaidah sosial tertentu yang dianut kelompok tersebut. Norma ini bisa bersifat negatif tetapi bisa juga positif. Norma yang negatif bisa menggiring remaja pada sikap permisif dalam kontak seksual, konsumsi alkohol dan narkotika, hingga perilaku kriminal. Sebaliknya, norma positif akan membawa remaja dalam lingkungan agamis, kecerdasan intelektual dan emosional, dan bentuk positif lainnya. Bagaimana remaja menentukan peer group-nya dapat tergantung pada beberapa kondisi, tetapi yang jelas salah satunya adalah faktor keluarga.

Lingkungan rumah (keluarga) membangun pondasi yang kuat dalam pikiran anak dan mencapai puncaknya saat dia memasuki masa remaja. Misalnya, anak yang "teraniaya" akan melampiaskan kemarahannya pada objek yang bisa dimanipulasinya (binatang kecil atau teman yang lebih kecil), dan ketika memasuki masa remaja hal ini mencapai puncak dengan perilaku yang lebih kejam. Dia juga akan lebih memilih menjadi penyendiri atau bergabung dengan peer group yang sejalan dengan pikirannya. Sebaliknya, anak yang dibesarkan dengan kasih sayang, juga akan memilih kelompok yang tidak jauh dengan sikap dan kepribadian yang dibangun di dalam keluarga.

Mungkinkah sebuah keluarga yang utuh dan harmonis menghasilkan anakanak remaja yang bermasalah. Secara umum tidak, namun setiap orang tua harus jujur mengakui adanya kesalahan dan kekeliruan dalam pengasuhan anak. Orang tua seyogianya tidak merasa benar sendiri, dengan dalih demi keutuhan dan keharmonisan keluarga. Utuh dan harmonis bisa dirasakan, bukan sekedar yang ditampakkan. Anak bisa menilai keharmonisan tersebut, dan menentukan sikap berdasarkan apa yang dilihat dan dirasakannya.

Orang tua mungkin bisa menyamarkan kondisi di rumah pada anak-anak karena keterbatasan kapasitas kognitif mereka, namun semakin sulit menutupi fakta dari seorang remaja. Menurut Piaget, salah seorang pakar perkembangan, masa remaja ditandai dengan peningkatan kemampuan kognitif; di periode ini anak mulai mampu menerima bentuk-bentuk abstrak, sehingga individu remaja mulai berpikir dan menalar pada lingkup yang lebih luas. Berkurangnya egosentrisme pada remaja memberikan peluang bagi orang tua untuk berkomunikasi secara lebih terbuka dan mendalam, dan memang remaja membutuhkan perlakuan yang berbeda dibandingkan dengan saat mereka masih

\footnotetext{
${ }^{11}$ John W. Santrock,op.cit., h. 18.
} 
anak-anak dulu. Satu lagi yang menjadi ciri remaja adalah budaya kontemporer, dan ini mau tidak mau harus menjadi perhatian orang tua. Budaya kontemporer yang dianut masa remaja mencakup di antaranya gaya berpakaian, piranti komunikasi dan audio-video semacam ponsel, gaya bicara, artis idola, jenis musik, tempat-tempat rendezvous yang "gaul", dan sebagainya. Sekalipun tidak menyukainya, orang tua perlu memberikan respek pada pengaruh budaya kontemporer semacam ini.

Jadi, perubahan pada individu dari periode anak-anak ke periode remaja bisa dikatakan sebagai proses transisi yang kompleks. Dari segi fisik dan fisiologis, terjadi perubahan dan perubahan tersebut signifikan, bisa dilihat dengan mata. Emosi dan kepribadian anak yang menginjak remaja juga berubah, dan di masa transisi ini terjadi beberapa kelabilan, yakni:

a. Remaja membutuhkan pengakuan bahwa mereka bukan anak-anak lagi. Untuk membuktikannya, mereka cenderung melakukan beberapa pembangkangan langsung maupun tidak langsung - karena meyakini bahwa orang dewasa bias mengambil keputusan sendiri. Remaja tidak ingin sekedar didikte, karena mereka mulai mau didengarkan. Perkembangan kapasitas intelektual dan emosi mereka memang sudah memungkinkan untuk diperlakukan lebih dewasa.

b. Dorongan alami remaja adalah bersosialisasi (seperti halnya orang dewasa), dan menempatkan kelompok di atas orang tua. Bentuk sosialisasi ini bisa berupa eksistensi/keberadaan dalam kelompok dan pengadopsian budaya kontemporer dalam pergaulan. Bila orang tua menyadari bahwa mereka adalah bagian dari masalah remaja, mereka dapat berupaya untuk mencari pertolongan profesional bagi keluarga. ${ }^{12}$

Bagaimanapun juga, rumah (keluarga) selalu menjadi tempat pulang bagi remaja dan mereka sebenarnya masih selalu ingin pulang kepada orang tua. Rumah yang terbuka dan dipenuhi dengan kehangatan komunikasi selalu dirindukan oleh remaja. Bila seorang remaja mulai menunjukkan perubahan ke arah yang negatif: bergaul dengan kelompok delinkuen (menyimpang/kriminal), pacaran yang mulai melebihi batas, berkenalan dengan alkohol dan rokok, memutar film porno, hampir dipastikan karena pengaruh teman akan tetapi telusuri akarnya di dalam keluarga. Dalam banyak kasus, anak yang mencari penyaluran di luar dikarenakan tersumbatnya komunikasi di rumah. Mungkin orang tua mau mendengarkan, tetapi tidak cukup bijak menyikapi mereka. Mungkin cukup bijak, tetapi kurang intensitas pertemuan. Orang tua haruslah cerdas dalam menghadapi remaja, karena remaja sudah mampu berpikir dan menalar. Bukan hanya harus cerdas, pertemuan yang terjadi haruslah intens dan dalam, agar orang tua mampu mendekatkan diri secara emosional dengan anak mereka.

Menjadi dewasa adalah sebuah proses, dan proses pertama disebut dengan masa remaja. Masa remaja adalah periode pencarian identitas diri, yang bertujuan menemukan konsep diri yang merupakan cetak biru kepribadiannya sebagai orang dewasa kelak. Masa remaja tidak akan terlewati dengan baik tanpa peran orang tua.

6. Yang Berperan dalam Mengatasi Pengaruh Negatif Teknologi Informasi dan Komunikasi pada Remaja Perspektif Pendidikan Islam

a. Peran keluarga

\footnotetext{
${ }^{12}$ john W. Santrock,op.cit., h. 36.
} 
Kegiatan agama yang bisa kita lakukan di rumah bersama keluarga itu banyak, sekecil-kecilnya adalah menjalankan ritual, seperti shalat berjemaah, berbuka dan sahur bersama, dan lain-lain. ${ }^{13}$ Lebih-lebih jika ditambah dengan kegiatan yang bisa memahamkan anak pada nilai-nilai agama yang bisa dipraktikkan dalam kehidupan sehari-hari, misalnya memahami Al-Quran atau lainnya. Agama bisa menjadi benteng anak, baik langsung atau tidak langsung.

Keluarga merupakan lingkungan pendidikan yang primer dan bersifat fundamental. Pendidikan dalam keluarga merupakan wahana yang paling strategis bagi pembentukan dan pengembangan semangat kebangsaan, karena dari keluargalah anak berasal. ${ }^{14}$ Bermodalkan pengalaman-pengalaman yang diperolehnya dalam keluarga inilah bergantung kelangsungan hidupnya. Peran keluarga antara lain:

1. Keluarga sebagai pusat pendidikan: disini orang tua berperan dalam pembentukan kepribadian remaja karena orang tua mendidik, mengasuh dan membimbing remajanya untuk hidup di dalam masyarakat.

2. Keluarga sebagai pusat agama: dengan kesadaran beragama yang diperoleh remaja-remaja dan bimbingan orang tua, remaja akan mengenal agama sehingga membuat mereka untuk berbuat soleh dalam kehidupan.

3. Keluarga sebagai pusat ketenangan hidup: dalam mempertahankan hidupnya sering orang mengalami gangguan pikiran, menemui frustasi dan untuk mendapatkan kekuatannya kembali maka keluarga adalah pangkalan yang paling vital.

Orang tua sebaiknya mempersiapkan diri untuk mengenal lebih jauh dalam membimbing anaknya saat masa remaja:

1. Kenali mereka lebih dekat yaitu informasi mengenai remaja dan perubahan-perubahan yang terjadi di dalam dirinya.

2. Kenali perubahan fisik pada remaja dan dampaknya terhadap diri anak.

3. Kenali perubahan emosi remaja dan caranya mencari perhatian orang tua serta reaksi emosinya dalam menghadapi masalah.

4. Menciptakan hubungan komunikasi yang hangat, membentuk kebiasaan-kebiasaan yang positif, memberlakukan aturan dalam keluarga, menyikapi "kesalahan" anak, "mengambil hati" anak dan "mencuri perhatian" anak.

5. Kenali perubahan lingkungan misalnya peran gender serta rasa keadilan antara pria dan wanita; teman dan permasalahannya; naksir, ditaksir dan pacaran.

6. Masalah-masalah seksualitas, kelainan seksual dan pengaruh buruk yang ada di masyarakat

b. Peran sekolah

Sekolah sebagai pusat pendidikan bagi siswa dalam rangka menimba pengetahuan, keterampilan seni budaya, olahraga serta meningkatkan budi pekerti yang luhur, untuk ini diperlukan sarana dan prasarana yang memadai serta perlu diciptakan lingkungan yang bersih,

\footnotetext{
13 Lidya Harlina Martono dan Satya Joewana,op.cit.,h. 25.

14 Muhammad Surya, Bina Keluarga,(Semarang: CV. Aneka Ilmu, 2003), h. 18.
} 
sehat, tertib serta aman agar dapat menunjang keberhasilan PBM karena itu guru perlu dapat menciptakannya. Lingkungan sekolah yang sehat dan dinamis. Guru adalah orangtua siswa di sekolah karena itu perlu adanya sikap berdialog guru dengan siswa tentang berbagai hal khusus tentang masalah belajar sehingga keberhasilan dalam belajar dapat tercapai.

Motivasi belajar siswa timbul dari dirinya sendiri sehingga siswa dapat belajar dengan tertib, patuh pada peraturan yang ada di sekolah dna tidak terpengaruh oleh hal-hal yang negatif. Program sekolah yang terpadu. Diberikan kegiatan intrakurikuler dan ekstrakurikuler secara terpadu. Melalui kegiatan pramuka, olahraga, kesenian, karya wisata, pencinta alam dan sebagainya, dapat memberikan aktivitas yang sehat dan dinamis serta bekal untuk masa depannya. ${ }^{15}$

c. Peran masyarakat

Usaha-usaha untuk menciptakan lingkungan sehat dan dinamis dalam kehidupan di masyarakat, kaum remaja dapat mengikuti berbagai kegiatan yang dilaksanakan oleh karang taruna, remaja masjid, KNPI atau oragnisasi pemuda lainnya. Bersama warga masyarakat remaja juga aktif dalam melaksanakan bakti sosial sehingga diperoleh pengalaman praktis yang positif dari kehidupan bermasyarakat. Hal ini untuk melatih fisik, mental, aktivitas dan kreativitas remaja sehingga terbentuk pribadi yang militant dan dinamis sebagai generasi penerus. Dalam organisasi remaja diharapkan dapat berkomunikasi dengan teman-temannya, membicarakan masalah-masalah atau kesulitan yang dialaminya dengan dibimbing oleh konsultan yang ada di dalam organisasi tersebut. ${ }^{16}$

Tidak hanya remaja yang belajar menghadapi kehidupannya yang "baru" tetapi orang tua juga perlu banyak belajar menghadapi perubahanperubahan dan menemukan cara terbaik untuk menghadapinya. Tahapan perkembangan remaja berbeda-beda pada setiap individu sehingga diperlukan pemahaman dan pengenalan secara dini setiap perubahan fisik dan mental yang terjadi pada remaja sehingga perlu diperhitungkan dalam membina dan mengembangkan remaja. Era teknologi informasi dan komunikasi sebagai aspek kemajuan IPTEK telah membuat segala informasi dan kemajuan dengan cepat tersebar ke segala penjuru dunia tetapi juga penyebaran pola perilaku yang kurang baik (gambar/video porno, blue film, pil koplo, putau, ekstasi, sabu-sabu dan lain-lain) akan cepat menjalar kemana-mana.

Agar terhindar dari pengaruh negatif dari era teknologi informasi dan komunikasi, maka diharapkan orangtua, keluarga, guru, dan masyarakat dapat membina remaja dengan baik, mengusahakan lingkungan hidup yang sebaik-baiknya agar remaja dapat berkembang ke arah yang diharapkan serta sesuai dengan kehendak dan kemauan anak itu sendiri tanpa mengikuti pola perilaku yang kurang baik yang sedang berkembang saat ini.

7. Langkah-langkah dalam Mengatasi Pengaruh Negatif Era Teknologi

Informasi dan Komunikasi

Langkah-langkah yang dapat dilakukan untuk mencegah dampak negatif era teknologi komunikasi dan informasi adalah bersikap waspada dan selektif

\footnotetext{
${ }^{15}$ Lidya Harlina Martono dan Satya Joewana,op.cit., h. 26.

16 Ibid., h. 29.
} 
terhadap segala macam arus era teknologi komunikasi dan informasi tersebut. Sikap selektif dapat diartikan sebagai sikap untuk memiliki dan menentukan alternatif yang terbaik bagi kehidupan diri, lingkungan masyarakat, bangsa, dan negara melalui proses yang berhati-hati, rasional, dan normatif terhadap segala macam pengaruh luar sehingga apa yang telah menjadi pilihan dapat diterima oleh semua pihak dengan penuh tanggung jawab.

Untuk mengatasi era teknologi komunikasi dan informasi juga dapat dilakukan dengan menumbuhkan kembali rasa nasionalisme bangsa agar masyarakat dapat mencintai negaranya. Langkah-langkah dapat dilakukan antara lain yaitu:

1. Menumbuhkan semangat nasionalisme yang tangguh, misal semangat mencintai produk dalam negeri.

2. Menanamkan dan mengamalkan nilai-nilai Pancasila.

3. Menanamkan dan melaksanakan ajaran agama.

4. Mewujudkan supremasi hukum, menerapkan dan menegakkan hukum dalam arti sebenar-benarnya dan seadil-adilnya.

5. Selektif terhadap pengaruh globalisasi di bidang politik, ideologi, ekonomi, sosial budaya bangsa. ${ }^{17}$

Dalam bidang teknologi dan informasi, langkah yang dapat ditempuh adalah dengan menyaring informasi yang baik dan bermanfaat. Selain itu juga diperlukan adanya pengawasan dari semua pihak agar informasi yang beredar di masyarakat tidak membawa dampak negatif terutama untuk remaja. Masyarakat juga harus berusaha mengikuti perkembangan IPTEK agar tidak tertinggal dari negara lain dan tidak mudah dibodohi oleh informasi-informasi yang masuk dari luar.

Untuk mengurangi sikap konsumtif, hendaknya setiap orang mempunyai kesadaran untuk tidak bergaya hidup yang bermewah-mewahan atau dapat dilakukan dengan membeli barang yang harganya lebih terjangkau namun mempunyai kualitas yang tidak jauh berbeda seperti produk-produk dalam negeri. Hal ini juga berkaitan dengan bidang ekonomi. Untuk mengurangi globalisasi dapat dilakukan dengan meningkatkan produksi dan kualitas produk dalam negeri agar dapat bersaing dengan produk luar. Promosi produk lokal melalui berbagai media massa juga dapat meningkatkan pengetahuan masyarakat tentang produk dalam negeri dan menarik konsumen untuk beralih pada produk lokal.

Dalam bidang budaya, masyarakat harus selektif memilih budaya dari luar dengan mengambil kebudayan-kebudayaan yang sesuai dengan kebudayaan lokal. Budaya lokal juga harus diangkat kembali dengan mengadakan berbagai macam pameran, seminar, lomba-lomba kebudayaan, dan sebagainya. Kebudayaan yang diwariskan secara turun-temurun harus terus dilestarikan agar tidak ada bagian yang tertinggal. Untuk mendukung hal tersebut juga dapat dilakukan dengan menjaga tempat-tempat bersejarah, wisata budaya, wisata alam, dan berbagai hal yang berkaitan dengan adat istiadat daerah.

Dalam bidang pendidikan juga tidak jauh berbeda. Pendidikan tidak akan pernah luput dari komponen-komponen yang saling memiliki keterkaitan yaitu pendidik (guru), peserta didik (murid), orang tua (keluarga), dan lingkungan. Ada beberapa hal yang perlu diperhatikan oleh semua komponen tersebut dalam menghadapi globalisasi di dunia pendidikan. Pendidik (guru) mempunyai tugas utama untuk mendidik, mengajar, membimbing, mengarahkan, melatih, menilai,

\footnotetext{
${ }^{17}$ https://metaluwitasari.wordpress.com/2013/04/03/langkah-tepat-menghadapi-globalisasi/
} 
dan mengevaluasi peserta didik dijalur pendidikan formal, pendidikan dasar, dan pendidikan menengah. Guru adalah orang yang bertanggung jawab atas peningkatan moral pelajar dan kemerosotannya. Oleh karena itu, tugas guru tidak terbatas pada kegiatan mengajar tapi yang terpenting adalah mencetak karakter murid. Dengan cara mendidik yang baik maka dapat terbentuk karakter murid yang baik dan kritis. Pembentukan karakter ini diperlukan agar murid dapat menanggapi dan menyaring pengaruh globalisasi dengan tepat. Hal tersebut juga dapat diperkuat dengan dukungan keluarga dan lingkungan sekitar. Kedua komponen ini harus lebih kuat menanamkan nilai-nilai dan norma-norma dalam masyarakat karena dengan penanaman tersebut anak akan lebih mempunyai sifat nasionalisme. Pengawasan juga harus dilakukan agar anak tidak terpengaruh oleh pihak luar dengan mudah.

Di samping itu, RPPH yang ada belum menjadi pedoman dalam pembelajaran di kelas. Bentuk pendampingannya, peneliti bersama guru model menilai dan meriview RPPM dan RPPH yang dibuat guru serta memberi catatan perbaikan. ${ }^{18}$

Langkah-langkah di atas tidak dapat dilaksanakan jika tidak ada peran aktif dari semua komponen negara baik pemerintah maupun masyarakat. Untuk itu diperlukan kerjasama yang baik agar hasilnya dapat maksimal. Kerjasama itu tidak lepas dari persatuan dan kesatuan bangsa sehingga pancasila sebagai ideologi negara harus dihidupkan kembali. ${ }^{19}$

8. Nilai Agama Dan Moral Yang Perlu Ditanamkan Pada Remaja Antara Lain Yaitu:

1. Tanamkanlah terhadap anak-anaknmu agar menyembah Allah dan berbakti kepada kedua orang tua. Hal ini sejalan denagn Firman Allah Ta'ala dalam surah Al-Isra : 23, yang artinya : "Dan Tuhanmu telah memerintahkan supaya kau jangan menyembah selain dia dan hendaklah kamu berbuat baik kepada Ibu-Bapakmu dengan sebaik-baiknya. Jika salah seorang diantara keduanya atau kedua-duanya sampai berumur lanjut dalam pemeliharaanmu, maka sekali-sekali janganlah kamu mengatakan kepada keduanya perkataan "ah" dan janganlah kamu membentak mereka dan ucapkanlah kepada mereka perkataan mulia".

2. Mengajak anak untuk melakukan shalat sejak usia dini dan membiasakan anak untuk berbuat baik, sebagaimana hadis Nabi yang artinya "jagalah anakmu agar selalu melaksanakan shalat, dan biasakanlah mereka berbuat baik, karena berbuat baik itu adalah kebiasaaan. (H.R.Thabrani).sejak kapankah anak harus shalat? Nabi bersabda yang artinya: "jika anak sudah bisa membedakan mana kanan dan kiri, maka perintahkanlah anak untuk shalat". (H.R.Abu Daud).

3. Membiasakan anak untuk saling tolong menolong. Sebagaimana firman Allah yang artinya: "Dan tolong menolonglah kamu (mengerjakan) kebajikan dan takwa, dan janganlah tolong menolong dalam berbuat dosa dan pelanggaran. (Al-Maidah: 2).

4. Didiklah anakmu dengan tiga perkara, sebagaimana hadis Nabi yang artinya: "didiklah anakmu dengan tiga perkara, yakni: mencintai Nabimu, mencintai keluarganya, dan membaca Al-Qur'an (H.R.Bukhari).

\footnotetext{
${ }^{18}$ Hunainah, H. (2019). Pendampingan Guru TK dalam Pengembangan Metode Pembelajaran Anak Usia Dini. ThufuLA: Jurnal Inovasi Pendidikan Guru Raudhatul Athfal, 7(2), 273-294.

19 Ibid
} 
5. Menanamkan nilai sosial pada anak agar gemar bersedekah, Nabi bersabda yang artinya: "apabila manusia meninggal dunia, amalnya akan terputus kecuali tiga perkara, yakni: sedekah jariah, ilmu yang bermanfaat, dan anak saleh yang selalu mendo'akan orang tuanya. (H.R.Tirmizi).

6. Ajarkanlah anakmu agar mereka suka bersikap lemah lembut. Sabda Nabi yang artinya: "hendaklah kamu berrsiikap lemah lembut, kasih sayang dan hindarilah sikap keras dan keji (H.R.Bukhari).

7. Biasakan anakmu agar jangan suka berdusta (Al-Baqarah: 10). Yang artinya: "dalam hati mereka ada penyakit, lalu ditambah Allah penyakitnya, dan bagi mereka sisksa yang pedih, disebabkan mereka berdusta.

8. Ajarilah anakmu agar jangan suka marah. Hadis Nabi yang artinya:'Dari Abu Hurairah, bahwasanya ada seorang laki-laki yang berkata kepada Nabi.Berilah wasiat kepadaku," Beliau menjawab," janganlah engkau marah ."Lelaki tersebut mengulang -ulang perkataannya beberapa kali, Beliau pun selalu menjawab, janganlah engkau marah.

9. Biasakanlah anakmu agar saling menyayangi antar sesamam muslim. Sebagaimana hadis nabi yang artinya : "Tidaklah kamu beriman sampai kamu menyintai saudaramu seperti kamu menyintai dirimu sendiri. (H.R.Bukhari dan Muslim)

10. Biasakanlah anakmu agar gemar membaca. Misalnya dengan membelikan buku-buku bergambar. Karena dengan membaca banyak pengetahuan yang diperoleh anak. Allah berfirman yang artinya : "Bacalah dengan (menyebut) nama Tuhanmu yang menciptakan, Dia telah menciptakan manusia dari segumpal darah, Bacalah dan Tuhanmulah Yang paling Pemurah, Yang mengajar (manusia) dengan perantaraan kalam , Dia mengajarkan kepada manusia apa yang tidak diketahuinya." (AL-Alaq:1-5).

11. Ajarilah agar anak kamu tidak suka mengadu domba. Sebagaimana hadis Nabi yang artinya : "Tidak akan masuk syurga bagi orang yang senang adu domba. (Muttafaqun Alaihi)".

12. Mendidik anak dari segi moral dan budi pekerti (akhlak). At-Tirmidzi meriwayatkan dari Ayyub Bin Musa, Rasulullah bersabda yang artinya: "tidak ada pemberian yang lebih berharga oleh seorang ayah kepada anaknya yang lebih utama dari pada pemberian budi pekerti yang baik".

Membiasakan anak untuk berolahraga dan bermain bersama. Hadis riwayat Al-Baihaqi yang artinya "ajarkanlah berenang dan memanah kepada anak- anak kalian. Dan suruhlah mereka melompat ke atas punggung kuda sekali lompatan"

\section{KESIMPULAN}

Berdasarkan uraian-uraian pada bab sebelumnya, maka penulis dapat menyimpulkan sebagai berikut:

1. Remaja adalah individu yang sedang berada pada masa peralihan dari masa anak-anak menuju masa dewasa dan ditandai dengan perkembangan yang sangat cepat dari aspek fisik.

2. Di era teknologi informasi dan komunikasi ini, setiap usaha dan kegiatan serta tindakan yang disengaja untuk mencapai suatu tujuan harus mempunyai landasan tempat berpijak yang baik dan kuat. Oleh karena itu, 
pendidikan Islam sebagai suatu usaha membentuk manusia, harus mempunyai landasan ke mana semua kegiatan dan semua perumusan tujuan pendidikan Islam itu dihubungkan.

3. Bentuk pengaruh negatif di era teknologi informasi dan komunikasi pada remaja adalah perilaku merokok, yang biasanya didapatkan dari lingkungan tempat tinggal, orang tua, ataupun teman-teman. Selain itu, adalah narkoba yang mempunyai pengaruh negatif, diantaranya; terganggu fungsi otak dan perkembangan normal remaja, keracunan, over dosis gejala putus zat, berulang kali kambuh, gangguan prilaku/mental-sosial, gangguan kesehatan, kendornya nilai-nilai, serta keuangan dan hukum.

4. Yang berperan dalam menanggulangi pengaruh negatif di usia remaja adalah orangtua, keluarga, guru dan masyarakat dapat membina remaja dengan baik, mengusahakan lingkungan hidup yang sebaik-baiknya agar remaja dapat berkembang ke arah yang kita harapkan serta sesuai dengan kehendak dan kemauan anak sendiri tanpa mengikuti pola perilaku yang kurang baik yang sedang berkembang saat ini.

\section{DAFTAR PUSTAKA}

Aly, Hery Noer dan Munzier,Watak Pendidikan Islam, (Jakarta: Friska Agung Insani, 2000).

Azizy, A. Qadri, Melawan Globalisasi; Reinterpretasi Ajaran Islam, (Yogyakarta: Pustaka

Pelajar,2004).

Azra, Azymardi, Pendidikan Islam; Tradisi dan Modernisasi Menuju Milenium Baru, (Jakarta: Logos

Wacana Ilmu, 2002)

Drajat, Zakiah, Pendidikan Islam dalam Keluarga dan Sekolah, (Jakarta: Ruhama, 1994).

Hunainah, H. (2019). Pendampingan Guru TK dalam Pengembangan Metode Pembelajaran

Anak Usia

Dini. ThufuLA: Jurnal Inovasi Pendidikan Guru Raudhatul Athfal, 7(2), 273-294.

http://dosenit.com/kuliah-it/teknologi-informasi/dampak-positif-dan-negatifpenggunaan-teknologi

informasi-dan-komunikasi

https://metaluwitasari.wordpress.com/2013/04/03/langkah-tepat-menghadapiglobalisasi/ Martono,

Lydia Harlina dan Satya Joewana,Pencegahan dan Penanggulangan Penyalahgunaan Narkoba

Berbasis Sekolah, (Jakarta: Balai Pustaka, 2006). Santrock, John W.,Live-Span Development;

Perkembangan Masa Hidup,(Jakarta:Erlangga, 2002).

Surya, Muhammad,Bina Keluarga,(Semarang: CV. Aneka Ilmu, 2003). 